\title{
Density, size and distribution of stomata in 35 rainforest tree species in Central Amazonia
}

\author{
Miguel Angelo Branco CAMARGOํㅗ Ricardo Antonio MARENCO²
}

\begin{abstract}
Stomata are turgor-operated valves that control water loss and $\mathrm{CO}_{2}$ uptake during photosynthesis, and thereby water relation and plant biomass accumulation is closely related to stomatal functioning. The aims of this work were to document how stomata are distributed on the leaf surface and to determine if there is any significant variation in stomatal characteristics among Amazonian tree species, and finally to study the relationship between stomatal density $\left(S_{\mathrm{D}}\right)$ and tree height. Thirty five trees $\left(>17 \mathrm{~m}\right.$ tall) of different species were selected. Stomatal type, density $\left(S_{D}\right)$, size $\left(S_{S}\right)$ and stomatal distribution on the leaf surface were determined using nail polish imprints taken from both leaf surfaces. Irrespective of tree species, stomata were located only on the abaxial surface (hypostomaty), with large variation in both $S_{D}$ and $S_{S}$ among species. $S_{D}$ ranged from 110 $\mathrm{mm}^{-2}$ in Neea altissima to $846 \mathrm{~mm}^{-2}$ in Qualea acuminata. However, in most species $S_{\mathrm{D}}$ ranges between 271 and $543 \mathrm{~mm}^{-2}$, with a negative relationship between $S_{D}$ and $S_{S}$. We also found a positive relationship between $S_{D}$ and tree height $\left(r^{2}=0.14\right.$, $p<0.01$ ), but no correlation was found between $S_{D}$ and leaf thickness. The most common stomatal type was anomocytic (37\%), followed by paracytic (26\%) and anisocytic (11\%). We conclude that in Amazonian tree species, stomatal distribution on the leaf surface is a response most likely dependent on the genetic background of every species, rather than a reaction to environmental changes, and that somehow $S_{D}$ is influenced by environmental factors dependent on tree height.
\end{abstract}

KEYWORDS: Amazonia, hypostomatous leaves, stomatal density, stomatal length, tropical rainforest.

\section{Densidade, tamanho e distribuição estomática em 35 espécies de árvores na Amazônia Central}

\section{RESUMO}

Estômatos são válvulas operadas a turgor que controlam a perda de água e a captura de $\mathrm{CO}_{2}$ durante a fotossíntese. Assim, as relações hídricas e o acumulo de biomassa vegetal são fortemente influenciadas pelo funcionamento estomático. Os objetivos deste trabalho foram: documentar como os estômatos estão distribuídos na superfície foliar e determinar se existe variação das características estomáticas entre espécies da Amazônia, estudar a relação entre densidade estomática $\left(S_{\mathrm{D}}\right)$ e altura arbórea. Trinta e cinco árvores (>17 m de altura) de diferentes espécies foram selecionadas. Tipo de complexo estomático, $S_{D}$, tamanho $\left(S_{S}\right)$ e distribuição na superfície foliar foram determinados utilizando impressóes de ambas as superfícies foliares com esmalte incolor. Independente da espécie, os estômatos foram encontrados apenas na superfície abaxial (hipoestomatia) com ampla variaçáo na $S_{D}$ e no $S_{S}$ entre espécies. A densidade estomática variou de $110 \mathrm{~mm}^{-2} \mathrm{em}$ Neea altissima a $846 \mathrm{~mm}^{-2} \mathrm{em}^{-2}$ Qualea acuminata. Entretanto, a maioria das espécies apresentou $S_{D}$ entre 271 e $543 \mathrm{~mm}^{-2}$, com uma relaçáo negativa entre $S_{D}$ e $S_{S}$ Observou-se uma relaçáa positiva entre $S_{D}$ e altura arbórea $\left(r^{2}=0.14, p<0.01\right)$, náo havendo relação entre $S_{D}$ e espessura foliar. Os tipos estomáticos mais comuns foram: anomocíticos (37\%), seguidos de paracíticos (26\%) e anisocíticos (11\%). Concluiu-se que em espécies da Amazônia, a distribuição de estômatos na superfície foliar está mais relacionada a fatores genéticos de cada espécie do que a variaçôes ambientais. Entretanto, $S_{D}$ é fortemente influenciada por fatores ambientais concernentes à altura da árvore.

PALAVRAS-CHAVE: Amazônia, densidade estomática, floresta tropical, folhas hipoestomáticas, tamanho estomático.

\footnotetext{
1 Programa de Pós-Graduação em Botânica-Instituto Nacional de Pesquisas da Amazônia (INPA), 69060-001 Manaus, AM, Brasil. branco@inpa.gov.br

2 Instituto Nacional de Pesquisas da Amazônia - Coordenação de Pesquisas em Silvicultura Tropical, (INPA-CPST), Av. André Araujo 2936, 69060-001 Manaus, AM, Brasil. rmarenco@inpa.gov.br
} 


\section{INTRODUCTION}

Stomata are small apertures on the leaf surface that regulate loss of water via transpiration and $\mathrm{CO}_{2}$ uptake during photosynthesis, and thereby water relation and plant biomass accumulation is influenced by stomatal movement (Al Afas et al. 2006; Bussis et al. 2006). Even in conditions when soil moisture is not a limiting factor for plant growth, the control of water loss is important to avoid leaf dehydration due to excessive transpiration, particularly in tall trees that may exhibit reduced hydraulic conductance (Hubbard et al. 1999). In a broad sense, transpiration depends on stomatal conductance $\left(\mathrm{g}_{\mathrm{s}}\right)$, net radiation received, temperature, wind speed and air to leaf vapour pressure difference (Jarvis and McNaughton 1986). The stomatal conductance to $\mathrm{CO}_{2}$ diffusion is a parameter that is governed by the density and aperture size of stomata (Farquhar and Sharkey 1982). Any change in stomatal conductance has implications at both the plant and regional or global scale. For example, the water lost by transpiration is an important regulator of the rainfall regime in the Amazon, as about $50 \%$ of annual rainfall in the Amazon comes from water vapor recycled in the region (Salati et al. 1978).

On the leaf surface, stomata may occur on both sides (amphistomatous leaves) or on either surface alone, usually the lower surface (hypostomatous leaves). Amphistomatous leaves are most commonly found in arid environments, whereas leaves with stomata only on the underside seem to be more common in plants of mesophytic habitats (Parkhurst 1978). On the other hand, although less common in nature, leaves with stomata only on the adaxial (upper) surface (epistomatous or hyperstomatous leaves) can be found in some floating plants, such as water lilies (Lawson 2009).

The amphistomatous trait has been correlated with leaf thickness (Parkhurst 1978), and it has been postulated that in thicker leaves, location of stomata on both leaf surfaces reduces internal diffusion resistance, as the occurrence of stomata on the upper surface decreases the pathway length of the $\mathrm{CO}_{2}$ molecules to carboxylation sites (Mott et al. 1982, Mott and Michaelson 1991). Thus, amphistomatous leaves would be advantageous when the internal $\mathrm{CO}_{2}$ concentration limits photosynthetic rates, as may occur in plants growing under high light intensity.

Stomatal density $\left(S_{D}\right)$ can vary within leaves, plants, and individuals of a single species (Al Afas et al. 2006). It can also vary due to environmental factors such as light, air humidity, water availability and atmospheric $\mathrm{CO}_{2}$ concentration (Woodward and Kelly 1995). In general, $S_{D}$ decreases with increase in $\left[\mathrm{CO}_{2}\right]$ and in comparison with leaves developed under low light intensity, sun leaves have higher stomatal densities (Givnish 1988).
In amphistomatous leaves, stomatal frequency is usually greater in the lower leaf surface than in the adaxial side (Volenikova and Ticha 2001; Tari 2003), and the adaxial to total $S_{D}$ ratio tends to decline with decreasing irradiance (James and Bell 2000). In trees, $S_{D}$ often ranges from 30 to $1190 \mathrm{~mm}^{-2}$ and guard cell length (hereafter referred to as stomatal size, $S_{S}$ ) from 10 to $50 \mu \mathrm{m}$ (Willmer and Fricker 1996), and often a negative relationship between $S_{D}$ and $S_{S}$ has been observed (Hetherington and Woodward 2003).

Changes in $S_{D}, S_{S}$ and stomatal location on the leaf surface in response to varying environmental conditions can affect stomatal conductance (Maherali et al. 2002), and thereby carbon assimilation, because there is a close relationship between photosynthesis and $\mathrm{g}_{\mathrm{s}}$ (e.g. Marenco et al. 2006). Thus, knowing how stomata are distributed on the leaf surface (one or both sides) is of major interest, not only because stomatal location can affect $\mathrm{CO}_{2}$ diffusion into the carboxylation sites, but also because latent heat transfer ( amount of energy used in transpiration) is related to the placement of stomata on the leaf surface (Jarvis and McNaughton 1986). In this study, we hypothesized that in response to high irradiance, stomata of forest canopy trees are located on both leaf surfaces for maximization of photosynthesis, with little variation in $S_{D}$ among species. Thus, the aims of this work were to document how stomata are distributed on the leaf surface of rainforest canopy trees, and to determine if there is any significant variation in stomatal characteristics among canopy tree species in central Amazonia, and finally to study the relationship between stomatal density and tree height.

\section{MATERIALS AND METHODS}

The study was conducted at the Tropical Forest Experiment Station (Reserve ZF2, $02^{\circ} 36^{\prime} 21^{\prime \prime}$ S, 60 08' $11^{\circ}$ " W) of the National Institute for Research in the Amazon (INPA) between October 2007 and September 2008. The study area is a pristine terra firme rainforest (105 $\mathrm{m}$ above sea level) in Brazilian Central Amazonia. The area has a humid tropical climate and an annual rainfall of $2240 \mathrm{~mm}$, with a rainy season from November to May and a dry period $(\leq 100 \mathrm{~mm}$ month $^{-1}$ ) between June and September. October is a dry-rainy season transition month. Mean temperature is about $27^{\circ} \mathrm{C}$. Above the canopy, relative humidity varies from $70 \%$ at noon to $100 \%$ at night. The soil type is an Oxisol (red-yellow latosol in the Brazilian classification) with a clay texture, low fertility and a $\mathrm{pH}$ of 4.5. Above the forest canopy, maximum photosynthetic flux density ranges between 1000 and 1300 $\mu \mathrm{mol} \mathrm{m} \mathrm{m}^{-2}$ (Dias 2009).

Thirty five trees (one tree per species, larger than $12 \mathrm{~cm}$ diameter at breast height, $\mathrm{D}_{\mathrm{BH}}$ ) of different species were selected at random in the study area (for scientific names see 
Table 1 in Results and Discussion). Small branches with leaves and reproductive structures (when available) were collected from the canopy of each tree (17 to $35 \mathrm{~m}$ from the ground, from the tallest part of the tree). Leaf samples were randomly detached from the branches, placed in a home-made press and squeezed between layers of paper (newspapers), then the leaves were dried in a forced air oven at $45^{\circ} \mathrm{C}$ until constant mass was reached (about one week). The layers of paper were replaced every two days during the dehydration process. Some corrugated cardboard sheets were added between the paper layers to enhance ventilation. Plant identification was made at the INPA's herbarium. For further verification, scientific names were cross-checked against the guide "Ducke reserve's flora" (Ribeiro et al. 1999). Tree height (H) was calculated using a $\mathrm{D}_{\mathrm{BH}}-\mathrm{H}$ equation (Nogueira et al. 2008): $\log _{10} \mathrm{H}=$ $0.842+0.394 \log _{10} \mathrm{D}_{\mathrm{BH}}$.

Type, density and size of stomata were determined in a sample of dehydrated leaves (five fully expanded leaves per plant and four samples per leaf) randomly taken from the plant material collected for plant identification. $S_{D}$ and $S_{S}$ were determined on nail polish imprints (Voleníková and Tichá 2001) taken from the adaxial and abaxial leaf surface, at the widest part of the leaf blade (middle region) and avoiding major veins. Stomata were counted under a light microscope (Leica DM500, Leica Microsystems, Wetzlar, Germany) on a field of view of $0.45 \mathrm{~mm}^{2}$ at a magnification of $400 x$, whereas $S_{S}$ was measured in a sample of 20 stomata per leaf at 1000x. In order to test if nail polish imprints were reliable to assess the stomatal type, in some leaves taken at random leaf epidermis was dissociated in a solution of glacial acetic acid and hydrogen peroxide $(1: 1 \mathrm{v} / \mathrm{v})$ at $60^{\circ} \mathrm{C}$ for $48 \mathrm{~h}$ (Franklin 1945), and images were taken with a digital camera coupled to the microscope (Canon, Sx100-IS, China). An optical reticle (accuracy of $1 \mu \mathrm{m}$ ) mounted on the eyepiece and calibrated against a micrometer slide (Nachet, Paris, France) was used for determining $S_{S}$. Dry leaf thickness was measured in 240- $\mathrm{mm}^{2}$-leaf circles (two per leaf) punched from the widest part of the leaf blade, and between the major veins with digital calipers, as previously described (Marenco et al. 2009). Data were subjected to analysis of variance. The Scott-Knott post-hoc test $(p<0.05)$ was used for mean separation. The relationship between $S_{D}$ and $S_{S}$ was examined by regression analysis using $S_{D}$ as the independent variable (Hetherington and Woodward 2003). As data had a normal distribution (Lilliefors 1967) no transformation was used before conducting analysis of variance. The SAEG 9.0 package of the Federal University of Viçosa, MG, Brazil was used for statistical analysis.

\section{RESULTS AND DISCUSSION}

Irrespective of tree species, stomata were located only on the abaxial surface (hypostomatous leaves) with significant difference in $S_{D}$ values among species (Table 1). Stomatal density ranged from $110 \mathrm{~mm}^{-2}$ in Neea altissima to $846 \mathrm{~mm}^{-2}$ in Qualea acuminata. However, in the majority of species, $S_{D}$ ranges between 271 and $543 \mathrm{~mm}^{-2}$. Stomatal size (guard cell length) ranged from $7.5 \mu \mathrm{m}$ in Eschweilera bracteosa to 22.5 $\mu \mathrm{m}$ in Ferdinandusa ellipttica, with a negative relationship between stomatal density and stomatal size $\left(r^{2}=0.36, p<0.05\right.$, Figure 1). Across species, $S_{D}$ tended to increase with tree height $\left(r^{2}=0.12, p<0.05\right.$, Figure 2$)$, but the regression equation could explain only $14 \%$ of the variance in stomatal density, indicating that other factors are involved in determining stomatal density. Throughout species the relationship between leaf thickness and tree height was not significant $\left(\mathrm{r}^{2}=0.03\right.$, $p>0.05$, Figure 3).

Regarding the stomatal type, we found that in most nail polish imprints $(86 \%)$ it was possible to identify the stomatal type. In Figure 4, the stomatal apparatus of Protium decandrum is shown using both nail polish imprint and the epidermis dissociation method. In this Figure, we can see that the stomatal complex is clearly recognizable in the nail imprint, and in both panels the stomatal patterns are fairly similar. This result allowed us to determine the stomatal types based on nail polish imprints. The most common stomatal type was anomocytic (37\% of species), followed by paracytic (26\%),

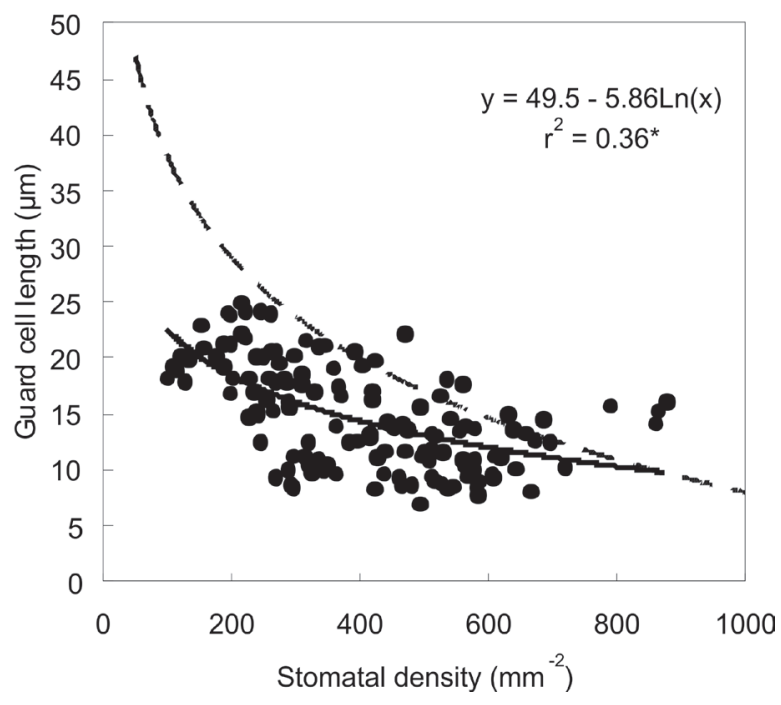

Figure 1 - Relationship between stomatal density $\left(S_{D}\right)$ and stomatal size $\left(S_{S}\right)$ on species studied. Each symbol represents a mean of four samples per leaf. For comparison, it is also shown (dashed line) the $S_{D}-S_{S}$ relationship described by the equation of Hetherington and Woodward (2003) for different plant groups, including grasses and fossil leaves. ${ }^{*}$ : significant at $p<0.05$. 
Table 1 - Species examined, type, density $\left(S_{D}\right)$ and size of stomata $\left(S_{S}\right)$, leaf thickness and tree height $(H)$ (mean \pm standard deviation).

\begin{tabular}{|c|c|c|c|c|c|c|}
\hline Specie & Family & Stomatal type & $S_{0}\left(m m^{-2}\right)$ & $\mathrm{S}_{\mathrm{s}}(\mu \mathrm{m})$ & $\begin{array}{c}\text { Leaf } \\
\text { thickness }(\mathrm{mm})\end{array}$ & $H(m)$ \\
\hline $\begin{array}{l}\text { Anisophyllea manausensis Pires \& W. A. } \\
\text { Rodrigues }\end{array}$ & Anisophyllaceae & anomocytic & $271 \pm 41 \mathrm{G}$ & $12.55 \pm 2 \mathrm{C}$ & $0.24 \pm 0.03 B$ & 25.8 \\
\hline Antonia ovata Pohl. & Gesneriaceae & anisocytic & $288 \pm 85 G$ & $15.05 \pm 1.7 \mathrm{C}$ & $0.19 \pm 0.01 \mathrm{D}$ & 23.6 \\
\hline Astronium lecointei Ducke & Anacardiaceae & anomocytic & $652 \pm 100 \mathrm{~B}$ & $12.5 \pm 2.2 \mathrm{E}$ & $0.21 \pm 0.03 C$ & 29.6 \\
\hline Couratari tauari 0. Berg. & Lecythidaceae & brachyparacytic & $223.5 \pm 32 \mathrm{H}$ & $15 \pm 3 D$ & $0.12 \pm 0.01 \mathrm{G}$ & 24.8 \\
\hline Duroia kotchubaeoides Steyerm & Rubiaceae & cyclocytic & $213.8 \pm 49 \mathrm{H}$ & $20 \pm 1.8 \mathrm{C}$ & $0.16 \pm 0.02 E$ & 33 \\
\hline Ecclinusa guianensis Eyma & Sapotaceae & ND & $316.5 \pm 17 \mathrm{G}$ & $13.7 \pm 1 \mathrm{~F}$ & $0.23 \pm 0.04 B$ & 29.7 \\
\hline Eschweilera bracteosa (Poepp. ex 0. Berg) Miers & Lecythidaceae & paracytic & $657.5 \pm 52 \mathrm{~B}$ & $12.5 \pm 1.7 \mathrm{E}$ & $0.16 \pm 0.01 \mathrm{E}$ & 25.4 \\
\hline Eschweilera apiculata (Miers) A. C. Sm. & Lecythidaceae & paracytic & $442 \pm 51 \mathrm{E}$ & $14 \pm 1.7 \mathrm{D}$ & $0.17 \pm 0.02 E$ & 27.6 \\
\hline Eschweilera coriacea (DC.) S.A. Mori & Lecythidaceae & paracytic & $406 \pm 37 \mathrm{~F}$ & $12.75 \pm 2 \mathrm{E}$ & $0.23 \pm 0.04 \mathrm{~B}$ & 32.3 \\
\hline Eschweilera parviflora (Aubl.) Miers & Lecythidaceae & paracytic & $333.4 \pm 37 \mathrm{D}$ & $11.25 \pm 1.7 \mathrm{G}$ & $0.16 \pm 0.03 E$ & 25.2 \\
\hline Ferdinandusa elliptica (Pohl. ) Pohl. & Rubiaceae & paracytic & $204.5 \pm 29 \mathrm{H}$ & $22.55 \pm 3 \mathrm{~A}$ & $0.29 \pm 0.01 \mathrm{~A}$ & 22.5 \\
\hline Geissospermum argenteum Woodson & Apocynaceae & anomocytic & $477.5 \pm 48 \mathrm{E}$ & $12.5 \pm 2 E$ & $0.13 \pm 0.009 \mathrm{G}$ & 23.7 \\
\hline Inga umbratica Poepp. \& Endl. & Fabaceae & anomocytic & $395.7 \pm 72 \mathrm{~F}$ & $15 \pm 2 D$ & $0.14 \pm 0.02 \mathrm{~F}$ & 25.3 \\
\hline Jacaranda copaia (Aubl.) D. Don & Bignoniaceae & anisocytic & $389.8 \pm 59 F$ & $17.5 \pm 2 \mathrm{C}$ & $0.12 \pm 0.01 \mathrm{G}$ & 30 \\
\hline Lecythis prancei S.A. Moni & Lecythidaceae & ND & $280.6 \pm 22 \mathrm{G}$ & $11.7 \pm 0.8 \mathrm{G}$ & $0.17 \pm 0.01 \mathrm{E}$ & 26.3 \\
\hline Licania adolphoduckei Prance & Chrysobalanaceae & paracytic & $458 \pm 55 E$ & $10.05 \pm 2 F$ & $0.19 \pm 0.01 \mathrm{D}$ & 22.8 \\
\hline Licaria chrysophylla (Meisn.) Kosterm. & Lauraceae & ND & $314 \pm 55 \mathrm{G}$ & $10 \pm 1.7 \mathrm{~F}$ & $0.23 \pm 0.01 \mathrm{~B}$ & 31.2 \\
\hline Licaria rodriguesii Kurz & Lauraceae & paracytic & $367 \pm 66 \mathrm{~F}$ & $8.55 \pm 1.8 \mathrm{~F}$ & $0.18 \pm 0.02 \mathrm{D}$ & 17.8 \\
\hline Matayba arborescens (Aubl.) Raldlk & Sapindaceae & anomocytic & $540.5 \pm 49 \mathrm{D}$ & $15 \pm 1.2 \mathrm{D}$ & $0.15 \pm 0.01 \mathrm{~F}$ & 16.6 \\
\hline Minquartia guianensis Aubl. & Olacaceae & paracytic & $519.3 \pm 42 \mathrm{D}$ & $10 \pm 0.7 \mathrm{G}$ & $0.18 \pm 0.08 \mathrm{E}$ & 23.1 \\
\hline Myrcia magnoliifolia DC. & Myrtaceae & anisocytic & $406 \pm 61 \mathrm{~F}$ & $20 \pm 1.8 \mathrm{~B}$ & $0.24 \pm 0.01 \mathrm{~B}$ & 27.7 \\
\hline Neea altissima Poepp. \& Endl. & Nyctaginaceae & brachyparatetra-cytic & $110.2 \pm 20 \mid$ & $24.5 \pm 1 C$ & $0.2 \pm 0.01 \mathrm{C}$ & 24.2 \\
\hline Neea oppositifolia Ruiz. \&. Pav. & Nyctaginaceae & anomocytic & $150 \pm 24 I$ & $22.5 \pm 2 \mathrm{~B}$ & $0.27 \pm 0.02 \mathrm{~A}$ & 19.4 \\
\hline Ouratea discophora Ducke & Ochnaceae & ND & $285.6 \pm 40 \mathrm{G}$ & $20.05 \pm 2.3 B$ & $0.17 \pm 0.04 \mathrm{D}$ & 16.8 \\
\hline Pouteria guianensis Aubl. & Sapotaceae & paracytic & $539.7 \pm 33 \mathrm{C}$ & $10.6 \pm 2 F$ & $0.23 \pm 0.02 B$ & 24.5 \\
\hline Pouteria jariensis Pires T.D. Penn & Sapotaceae & anomocytic & $284.5 \pm 24 \mathrm{G}$ & $15 \pm 1.7 \mathrm{C}$ & $0.16 \pm 0.01 \mathrm{E}$ & 18.8 \\
\hline Pouteria reticulata (Engl.) Eyma & Sapotaceae & ND & $277.8 \pm 41 \mathrm{G}$ & $20 \pm 2 B$ & $0.13 \pm 0.02 \mathrm{~F}$ & 27.5 \\
\hline Pouteria retinervis T. D. Penn & Sapotaceae & anomocytic & $212 \pm 19 \mathrm{H}$ & $17.5 \pm 1.6 \mathrm{~A}$ & $0.14 \pm 0.02 \mathrm{~F}$ & 20.6 \\
\hline Protium crassipetalum Cuatrec., & Burseraceae & anomocytic & $581 \pm 33 \mathrm{C}$ & $5.5 \pm 1 \mathrm{G}$ & $0.14 \pm 0.02 \mathrm{~F}$ & 19.4 \\
\hline Protium decandrum (Aubl.) Marsh. & Burseraceae & anomocytic & $588.5 \pm 77 \mathrm{C}$ & $7.5 \pm 1 \mathrm{G}$ & $0.16 \pm 0.01 \mathrm{E}$ & 35.9 \\
\hline Protium klugii J.F. Macbr. & Burseraceae & anomocytic & $589.3 \pm 64 \mathrm{C}$ & $10 \pm 0.9 \mathrm{~F}$ & $0.2 \pm 0.02 \mathrm{C}$ & 22 \\
\hline Qualea acuminata Spruce ex. Warm & Vochysiaceae & cyclocytic & $864.6 \pm 73 \mathrm{~A}$ & $17.5 \pm 1.8 \mathrm{D}$ & $0.2 \pm 0.03 \mathrm{C}$ & 19 \\
\hline Rinorea paniculata (Mart.) Kuntze & Violaceae & anisocytic & $175.4 \pm 29 \mid$ & $22.5 \pm 2 B$ & $0.18 \pm 0.009 \mathrm{D}$ & 31.6 \\
\hline Scleronema micranthum (Ducke) Ducke & $\begin{array}{l}\text { Malvaceae: } \\
\text { Bombacaceae }\end{array}$ & anomocytic & $526.2 \pm 42 \mathrm{D}$ & $15 \pm 2.3 \mathrm{C}$ & $0.18 \pm 0.03 \mathrm{D}$ & 20 \\
\hline Swartzia ingifolia Ducke & Fabaceae & anomocytic & $543.8 \pm 49 \mathrm{D}$ & $15 \pm 2 E$ & $0.15 \pm 0.03 \mathrm{~F}$ & 23.4 \\
\hline
\end{tabular}




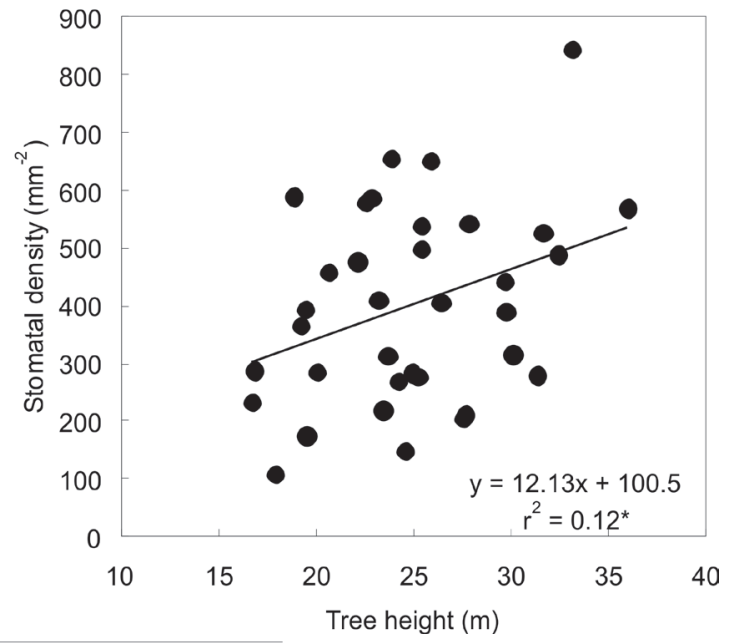

Figure 2 - Relationship between stomatal density $\left(S_{D}\right)$ and tree height $(H)$ in 35 examined species. Each symbol represents a mean of five fully expanded leaves per plant and four samples per leaf. ${ }^{*}$ : significant at $p<0.05$.

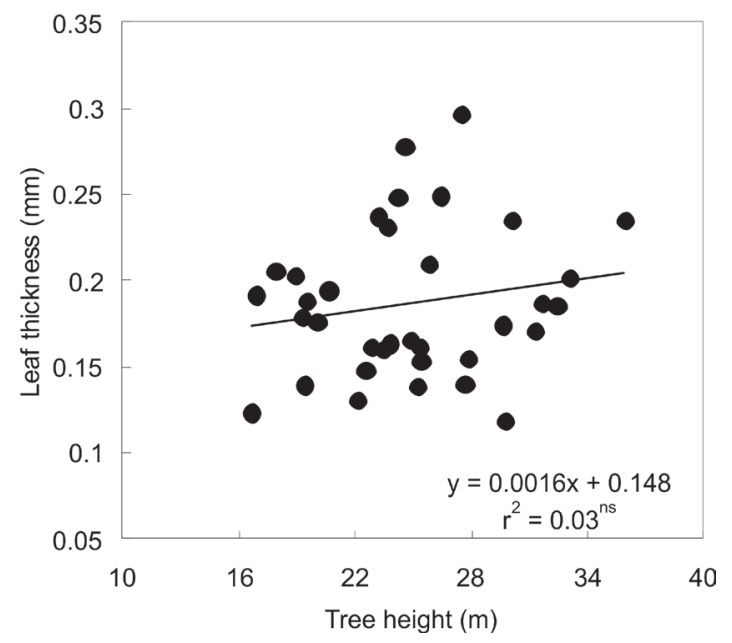

Figure 3 - Relationship between leaf thickness and tree height $(H)$. Each symbol represents a mean of five leaves per plant and four samples per leaf. ns: not significant $(p>0.05)$.

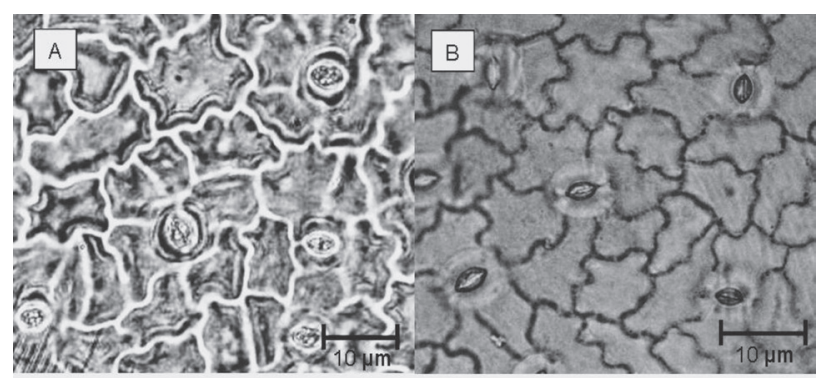

Figure 4 - Photomicrographies of the abaxial leaf surface taken from either a nail polish imprint (A) or a dissociated epidermis (B) to illustrate the reliability of the nail imprint method. In these images the stomatal type of Protium decandrum is shown (anomocytic type: the pair of guard cells surrounded by five unspecialized epidermal cells). anisocytic (11\%) and cyclocytic (6\%, Table 1). In $14 \%$ of examined species, the stomatal type was not discernible in the imprints of the leaf surface.

Regardless of tree species stomata were observed only on the abaxial and not on the adaxial surface (hypostomatous leaves). Hypostomaty occurred even in the tallest trees, which are subjected to a high level of overhead irradiance on the whole crown (Rozendaal et al. 2006). This result negates our initial hypothesis and is against what could be expected from leaves grown under high irradiance (Ticha 1982; Lake et al. 2001; Casson and Gray 2008). For example, in Scrophularia californica var. floribunda Greene (Scrophulariaceae), leaves produced in full sunlight were amphistomatous, but hypostomatous if developed under deep shade conditions (Mott et al. 1982). Also, leaves of Ambrosia cordifolia (A. Gray) W.W. Payne (Asteraceae) were hypostomatous when developed at low light intensities, but amphistomatic under high light intensities (Mott and Michaelson 1991).

If amphistomaty is advantageous to plants when a high maximum leaf conductance is required (Mott et al. 1982), then the absence of amphistomatous leaves in rainforest trees suggests that maximum photosynthetic rates are limited by factors other than the maximum conductance of the leaf. It has been postulated that amphistomaty seems to be a leaf adaptation in response to high light intensity (Mott et al. 1982; James and Bell 2000). However, our results indicate that amphistomaty is not an acclimation response, but a long-term evolutionary and adaptive strategy whereby plants alter anatomical leaf traits to cope with permanent changes in environmental conditions.

An advantage of distributing stomata over both leaf surfaces is to double the boundary layer conductance, hence, amphistomatous leaves could be advantageous in environments when photosynthetic rates can be potentially limited by a low leaf conductance, as could be the case in leaves exposed to high irradiance. A high maximum leaf conductance makes possible the leaf to achieve high photosynthetic rates in full sunlight, particularly when water supply does not limit stomatal opening. Even when stomatal placement on both leaf surfaces seems to be advantageous under high irradiance, amphistomatous leaves were not observed even in the highilluminated canopy leaves of the tallest trees, which suggests that amphistomaty is most likely determined by the genetic background of each species (Berger and Altmann 2000), rather than by changes in the physical environment throughout the plant life cycle. This hypothesis is in agreement with the findings of Camargo (2009) who observed that both saplings (growing beneath the forest canopy) and adult canopy trees have only hypostomatous leaves. Indeed, it has been suggested that, hypostomaty is considered the primitive trait in land plants, and amphistomaty the derived state for stomatal 
distribution; thus, vascular cryptogams are almost exclusively hypostomatic (Mott et al. 1982). It seems that trees tend to be hypostomatic and non-woody plants to have hypostomatic or amphistomatic leaves (Peat and Fitter 1994)

In Eucalyptus globulus Labill., although environmental brightness affects the adaxial to total $S_{D}$ ratio (amphistomatous index), even shade leaves had stomata on the adaxial surface (James and Bell 2000), indicating that although the intensity of the amphistomatous trait is modulated by environmental condition, its occurrence is determined by the genetic makeup of each species. The increase in $S_{D}$ with tree height is most likely related to an increase in crow exposure, as irradiance increases with plant stature (Rozendaal et al. 2006). However, the effect of changes in light quality with tree height cannot be ruled out. It has been shown that blue light causes an increase in stomatal density in some soybean lines (Liu-Gitz et al. 2000), and that a low red to far red ratio may lead to a decrease stomatal density (Schoch et al. 1984; Boccalandro et al. 2009). As leaves selectively absorb the photosynthetically active wavelengths, the canopy shade is depleted in blue and red light but enriched in far red radiation, so the R/Fr ratio varies from 1.2 above the canopy to about 0.5 under the forest canopy (Smith 1982). Thus, changes in light quality (variation in spectral composition) and quantity along the vertical canopy profile could explain, at least in part, the trend for $S_{D}$ to increase with tree height. This is consistent with Meidner and Mansfield (1968) who postulate that on a single plant, leaves of higher position on the stem tend to have smaller stomata but a higher $S_{D}$ than lower leaves.

We found a slight trend for leaf thickness to increase with tree height, however the determination coefficient was low and not significant $\left(r^{2}=0.03, p>0.05\right.$, Figure 3). A decrease in leaf thickness has often been observed in leaves developed under low red/far-red conditions (Franklin et al. 2005) or low light levels (Givnish 1988). Location of stomata on both leaf surfaces can reduce the mesophyll resistance to $\mathrm{CO}_{2}$ diffusion which constitutes an advantage for plants with thick leaves (Parkhurst 1978). In 38 species of the Bursera genus (Burseraceae) there was a close relationship between leaf thickness and the amphistomatous trait (Mott et al. 1982). However, this trend was not observed in the 35 tree species examined in this study.

In central Amazonia, relative air humidity and irradiance can vary from $90-100 \%$ and $0.3-0.6 \mathrm{~mol} \mathrm{~m}^{-2} \mathrm{day}^{-1}$ at the forest floor to about $60-70 \%$ and $25-30 \mathrm{~mol} \mathrm{~m}^{-2}$ day $^{-1}$ above the forest canopy (Dias 2009; Mendes an Marenco 2010), which may affect $S_{D}$. In Tradescantia virginiana, stomatal density was higher for plants grown in dry air $(55 \%$ relative humidity$\mathrm{RH}$ ) than in those kept constantly at 90\% RH (Nedjad and van Meeteren 2005). However, the negative effect of humid air on $S_{D}$ was not observed in other herbaceous plants, such as Lycopersicon esculentum Mill., Capsicum annuum L. and Solanum melongena L. (Bakker 1991), indicating that the response to air humidity is species-specific.

We found an inverse relationship between stomatal density and size, which is consistent with results obtained by others (Hetherington and Woodward 2003; Nejad and van Meeteren 2005; Pearce et al. 2006). However, $S_{S}$ values observed in this study are lower than those reported by Hetherington and Woodward (2003), particularly at low $S_{D}$ (Figure 1). Although $S_{S}$ decrease with $S_{D}$, there is not a clear relationship between stomatal density and stomatal conductance $\left(\mathrm{g}_{\mathrm{s}}\right)$, which finally affect photosynthetic rates. In Azadirachta indica A. Juss. (Meliaceae), for example, $S_{D}$ was positively correlated with net photosynthesis and biomass production (Walton 1974; Araus et al. 1986; Kundu and Tigerstedt 1998). Also in Populus spp $S_{D}$ was positively correlated with stomatal conductance (Pearce et al. 2006). However, in other studies, stomatal density did not significantly affect $\mathrm{g}_{\mathrm{s}}$ or photosynthetic rates (Teare $e t$ al. 1971; Miskin et al. 1972; Bakker 1991). The fact that a positive relationship was found between $S_{D}$ and tree height is consistent with the hypothesis that $S_{D}$ is influenced by the light environment (Casson and Gray 2008). In Arabidopsis thaliana (L.) Heynh. (Brassicaceae), a reduction in $S_{D}$ can be compensated by an increase in stomatal aperture (Bussis et al. 2006). However, in Zea mays L. (Poaceae) a negative relationship between $S_{D}$ and photosynthetic capacity can be found (Heichel 1971). Thus, with data now available it is difficult to categorically conclude how an increase in $S_{D}$ can influence $g_{s}$ in Amazonian tree species, although variation in tree height per se can lead to a decline in $\mathrm{g}_{\mathrm{s}}$ due to an increased hydraulic resistance to sap flow with plant stature (Schäfer $e t$ al. 2000).

Contrary to our expectations, increase in irradiance levels from the forest floor to the upper canopy did not affect stomatal placement on the leaf surface, suggesting that amphistomaty is not an acclimation response to changes in illumination during the plant life cycle. The large variation in $S_{D}$ among species indicates that the genetic constitution of species play a major role in determining $S_{D}$, although, somehow environmental factors related to tree height (e.g. light intensity, air humidity or light quality) finally modulate the stomatal frequency of a given leaf.

\section{ACKNOWLEDGEMENTS}

We thank the Ministry of Science and Technology MCT/ INPA, FAPEAM (project PIPT-1746-08), CAPES and CNPq. 


\section{REFERENCES}

Al Afas, N.; Marron, N.; Ceulemans, R. 2006. Clonal variation in stomatal characteristics related to biomass production of 12 poplar (Populus) clones in a short rotation coppice culture. Enviromental and Experimental Botany, 58: 279-286.

Araus, J.L.; Alegre, L.; Tapia, L.; Calafell, R.; Serret, M.D. 1986. Relationship between photosynthetic capacity and leaf structure in several shade plants. American Journal of Botany, 73: 17601770 .

Bakker, J.C. 1991. Effects of humidity on stomatal density and its relation to leaf conductance. Scientia Horticulturae, 48: 205-212.

Berger, D.; Altmann, T. 2000. A subtilisin-like protease involved in the regulation of stomatal density and distribution in Arabidopsis thaliana. Genes and Development, 14: 1119-1131.

Boccalandro, H.E.; Rugnone, M.L.; Moreno, J.E.; Ploschuk, E.L.; Serna, L.; Yanovsky, M.J.; Casal, J.J. 2009. Phytochrome B enhances photosynthesis at the expense of water-use efficiency in Arabidopsis. Plant Physiology, 150: 1083-1092.

Bussis, D.; Von Groll, U.; Fisahn, J.; Altman, T. 2006. Stomatal aperture can compensate altered stomatal density in Arabidopsis thaliana at growth light conditions. Functional Plant Biology, 33: 1037-1043.

Camargo, M.A.B. 2009. Stomatal characteristics in tree species of Central Amazonia. Dissertação de Mestrado, Instituto Nacional de Pesquisas da Amazônia (INPA)/Universidade Federal do Amazonas, Manaus, Amazonas. 52 pp. [in Portuguese]

Casson, S.; Gray, J.E. 2008. Influence of environmental factors on stomatal development. New Phytologist, 178: 9-23.

Dias, D.P. 2009. Photosynthesis and diameter increment of trees as a function of temperature and precipitation in a terra firme rain forest in Central Amazonia. Tese de doutorado, Instituto Nacional de Pesquisas da Amazônia/Universidade Federal do Amazonas, Manaus, Amazonas. 123 pp. [in Portuguese].

Farquhar, G.D.; Sharkey, T.D. 1982. Stomatal conductance and photosynthesis. Annual Review of Plant Physiology, 33: 317-345.

Franklin, G.L. 1945. Preparation of thin sections of synthetic resins and wood-resin composites, and a new macerating method for wood. Nature, 155: 51-51.

Franklin, K.A.; Whitelam, G.C. 2005. Phytochromes and shadeavoidance responses in plants. Annals of Botany, 96: 169-175.

Givnish, T.J. 1988. Adaptation to sun and shade: a whole-plant perspective. Australian Journal of Plant Physiology, 15: 63-92.

Heichel, G.H. 1971. Stomatal movements, frequencies and resistances in two maize varieties differing in photosynthetic capacity. Journal of Experimental Botany, 22: 644-649.

Hetherington, A.M.; Woodward, F.I. 2003. The role of stomata in sensing and driving environmental change. Nature, 424: 901-908.

Hubbard, R.M.; Bond, B.J.; Ryan, M.G. 1999. Evidence that hydraulic conductance limits photosynthesis in old Pinus ponderosa trees. Tree Physiology, 19: 165-172.

James, A.S.; Bell, D.T. 2000. Influence of light availability on leaf structure and growth of two Eucalyptus globulus ssp globulus provenances. Tree Physiology, 20: 1007-1018.
Jarvis, P.G.; McNaughton, K.G. 1986. Stomatal control of transpiration: scaling up from leaf to region. Advances in Ecological Research, 15: 1-49.

Kundu, S.K.; Tigerstedt, P.M.A. 1998. Variation in net photosynthesis, stomatal characteristics, leaf area and whole-plant phytomass production among ten provenances of neem (Azadirachta indica). Tree Physiology, 19: 47-52.

Lake, J.A.; Quick, W.P.; Beerling, D.J.; Woodward, F.I. 2001. Plant development: Signals from mature to new leaves. Nature, 411 154-154.

Lawson, T. 2009. Guard cell photosynthesis and stomatal function. New Phytologist, 181: 13-34.

Lilliefors, H. 1967. On the Kolmogorov-Smirnov test for normality with mean and variance unknown. Journal of the American Statistical Association, 62: 399-402.

Liu-Gitz, L.; Britz, S. J.; Wergin, W. P. 2000. Blue light inhibits stomatal development in soybean isolines containing kaempferol3-O-2 ${ }^{\mathrm{G}}$-glycosyl-gentiobioside (K9), a unique flavonoid glycoside. Plant, Cell and Environment, 23: 883-891.

Maherali, H.; Reid, C.D.; Polley, H.W.; Johnson, H.B.; Jackson, R.B. 2002. Stomatal acclimation over a subambient to elevated $\mathrm{CO}_{2}$ gradient in a $\mathrm{C}_{3} / \mathrm{C}_{4}$ grassland. Plant, Cell and Environment, 25: 557-566.

Marenco, R.A.; Antezana-Vera, S.A.; Nascimento, H.C.S. 2009. Relationship between specific leaf area, leaf thickness, leaf water content and SPAD-502 readings in six Amazonian tree species. Photosynthetica, 47: 184-190.

Marenco, R.A.; Siebke, K.; Farquhar, G.D.; Ball, M.C. 2006. Hydraulically based stomatal oscillations and stomatal patchiness in Gossypium hirsutum. Functional Plant Biology, 33: 1103-1113.

Meidner, H.; Mansfield, T.A. 1968. Physiology of stomata. McGraw Hill, London. 179 pp.

Mendes, K.R.; Marenco, R. A. 2010. Leaf traits and gas exchange in saplings of native tree species in the Central Amazon. Scientia Agricola, 67:624-632.

Miskin, K.E.; Rasmusso.D.C.; Moss, D.N. 1972. Inheritance and physiological effects of stomatal frequency in barley. Crop Science, 12: 780-783.

Mott, K.A.; Gibson, A.C.; O'Leary, J.W. 1982. The adaptive significance of amphistomatic leaves. Plant, Cell and Environment, 5: 455-460.

Mott, K.A.; Michaelson, O. 1991. Amphistomy as an adaptation to high light-intensity in Ambrosia cordifolia (Compositae) American Journal of Botany, 78: 76-79.

Nejad, A.R.; van Meeteren, U. 2005. Stomatal response characteristics of Tradescantia virginiana grown at high relative air humidity. Physiologia Plantarum, 125: 324-332.

Nogueira, E.M.; Nelson, B.W.; Fearnside, P.M.; Franca, M.B.; de Oliveira, A.C.A. 2008. Tree height in Brazil's 'arc of deforestation': Shorter trees in south and southwest Amazonia imply lower biomass. Forest Ecology and Management, 255: 2963-2972. 
Parkhurst, D.F. 1978. The adaptive significance of stomatal occurrence on one or both surfaces of leaves. Journal of Ecology, 66: 367-383.

Pearce, D.W.; Millard, S.; Bray, D.F.; Rood, S.B. 2006. Stomatal characteristics of riparian poplar species in a semi-arid environment. Tree Physiology, 26: 211-218.

Peat, H.J.; Fitter, A.H. 1994. A comparative study of the distribution and density of stomata in the British flora. Biological Journal of the Linnean Society, 52: 377-393.

Ribeiro, J.E.L.S.; Hopkins, M.J.G.; Vicentini, A.; Sothers, C.A.; Costa, M.A.S.; Brito, J.M.; Souza, M.A.D.; Martins, L.H.P.; Lohmann, L.G.; Assunção, P.A.C.L.; Pereira, E.C.; Silva, C.F.; Mesquita, M.R.; Procópio, L.C.(ed.). 1999. Ducke reserve’s flora. Identification guide of vascular plants in a terra firme forest in Central Amazonia. Instituto Nacional de Pesquisas da Amazônia, Manaus, 793 pp. [in Portuguese].

Rozendaal, D.M.A.; Hurtado, V.H.; Poorter, L. 2006. Plasticity in leaf traits of 38 tropical tree species in response to light; relationships with light demand and adult stature. Functional Ecology, 20: 207-216.

Salati, E.; Marques, J.; Molion, L.C.B. 1978. Origin and distribution of rain in the Amazon basin. Interciencia. 3: 200-205. [in Portuguese]
Schäfer, K.V.R.; Oren, R.; Tenhunen, J.D. 2000. The effect of tree height on crown level stomatal conductance. Plant, Cell and Environment, 23: 365-375.

Schoch, P. G.; Jacques, R.; Lecharny, A.; Sibi, M. 1984. Dependence of the stomatal index on environmental factors during stomatal differentiation in leaves of Vigna sinensis L. II. Effect of different light quality. Journal of Experimental Botany, 35: 1405-1409.

Smith, H. 1982. Light quality, photoperception, and plant strategy. Annual Review of Plant Physiology, 33: 481-518.

Tari, I. 2003. Abaxial and adaxial stomatal density, stomatal conductances and water status of bean primary leaves as affected by paclobutrazol. Biologia Plantarum, 47: 215-220.

Teare, I.D.; Peterson, C.J.; Law, A.G. 1971. Size and frequency of leaf stomata in cultivars of Triticum aestivum and other Triticum species. Crop Science, 11: 496-498.

Ticha, I. 1982. Photosynthetic characteristics during ontogenesis of leaves.7. Stomata density and sizes. Photosynthetica, 16:375-471.

Voleníková, M.; Tichá, I. 2001. Insertion profiles in stomatal density and sizes in Nicotiana tabacum L. plantlets. Biologia Plantarum, 44: 161-165.

Walton, P.D. 1974. The genetics of stomatal length and frequency in clones of Bromus inermis and the relationships between these traits and yield. Canadian Journal of Plant Science, 54: 749-754.

Willmer, C.; Fricker, M. 1996. Stomata. $2^{\text {nd }}$ Ed, Chapman and Hall, London, UK. 375 pp.

Woodward, F.I.; Kelly, C.K. 1995. The influence of $\mathrm{CO}_{2}$ concentration on stomatal density. New Phytologist, 131: 311327.

Recebido em 20/01/2010

Aceito em 07/08/2010 